\title{
The Implementation of Quantum Teaching Learning Model to Improve Learning Outcomes of Class V Students SD Borong Jambu II of Makassar
}

\author{
Bellona Mardhatillah Sabillah', ${ }^{1}{ }^{*}$ \& Sukmawati2 \\ ${ }^{1}$ Elementary Teacher and Education Program, Faculty of Teachers Training and Education, Megarezky \\ University, Makassar, 90234, Indonesia \\ 2 Department of English Education, Faculty of Teachers Training and Education, Megarezky University, \\ Makassar, 90234, Indonesia \\ a bellona.sabillah@gmail.com; b sukmar.dilla@gmail.com \\ *Corresponding Author : bellona.sabillah@gmail.com [ Phone : 081343825211 ]
}

\begin{abstract}
This study aims to improve social studies learning outcomes in grade V at SD Borong Jambu II Makassar by implementing the quantum teaching-learning model. This research is a Classroom Action Research (PTK), which is divided into two cycles with four stages, namely: planning, acting, observing, and reflecting repeatedly. The subjects of this study were students of grade V at SD Borong Jambu II Makassar, totaling 30 students. The instruments used to obtain data in this study consisted of tests, observation sheets, and questionnaires. This data analysis technique was carried out by analyzing learning outcome data, analyzing data from interviews, and analyzing field note data. The pre-action results were $33.33 \%$ who got a value of $\geq 75$, then after learning using the quantum teaching model increased to $60 \%$ in cycle I increased to 30 students or all students earned a score of $\geq 75$ in cycle II. It can be concluded that learning using the quantum teaching model by doing variations shows that the criteria for success in the study are fulfilled. This can be seen from the increase in grade V students in social studies score at SD Borong Jambu II of Makassar.
\end{abstract}

Keywords: Quantum; Teaching-learning; Learning model; Outcomes;

\section{Introduction}

Education is a means to develop science and technology (ICT). All subjects have been developed to aim at the birth of intellectuals who can be relied on as agents of change who can bring a better country and compete with other countries. Efforts to improve the quality of education continue to be made in the form of teachers' efforts when teaching both by lecture and discussion methods. priority in science learning. They are expected to be more independent in constructing their knowledge during the learning process (Sujarwo et al., 2019).

It happens in the field that students are often lazy in class. They ignore the teacher's orders to do the assignment given. Students do this by copying their friends' work. The presentation did not go as expected by the teacher. Students only came to the front with the origin of reading, while those in the back rarely listened to it. Students have no intention of learning, so learning in class requires more active learning. According to Djamarah in Astriani Wangka \& Mustahidang U. (2017:69 in Sujarwo; Sukmawati; Yahrif, 2019)) stated that education is conscious effort and aims to develop quality, it is a process in order to influence students to adapt themselves as best toward their environment and thus will cause changes themselves that to be able to adapt people's lives According to researchers, looking at the existing problems, one of the appropriate learning models is the quantum teaching model. A'la (2010) argues that quantum teaching is an orchestration of various interactions that exist in and around learning moments. This is in line with the Classroom Action research conducted by Jumiyanto (2012), that the application of TANDUR in quantum teaching can increase student motivation and learning achievement in each cycle. 
According to (DePorter et al, 2012), by applying the quantum teaching-learning model in the classroom, a teacher can create a pleasant learning atmosphere to affect student learning outcomes. Quantum teaching is a learning model that involves students' active role while still bringing out the characteristics of the language, namely students can develop their knowledge with scientific evidence, especially social studies subjects for students to learn. Some teachers and students still face many problems during the learning process. There are various responses found in the classroom related to these problems, especially in students' attitudes during the learning process, student learning outcomes, and participation in carrying out group activities.

\section{Methods}

This research is a Classroom Action Research (CAR) divided into two cycles with four stages: planning, acting, observing, and reflecting repeatedly. This research was conducted at SD Borong Jambu II Makassar. The instruments used to obtain data in this study consisted of tests, observation sheets, and questionnaires.

\section{Results and Discussion}

Before the research, the initial activity was to observe the social studies learning process in grade $\mathrm{V}$ at SD Borong Jambu II Makassar. Initial data in social studies learning outcomes data for fifth-grade students of SD Borong Jambu II Makassar were obtained through a pre-test. The pre-test results can also be used as a reference for researchers and teachers in learning the quantum teaching model so that student learning outcomes can improve. The results of the pre-test carried out can be seen in the table 1.

\begin{tabular}{cccc}
\multicolumn{5}{c}{ Table 1. The Initial Activity } \\
\hline No. & Score & Frequency & KKM \\
\hline 1 & 90 & 1 & 75 \\
\hline 2 & 85 & 2 & 75 \\
\hline 3 & 80 & 2 & 75 \\
\hline 4 & 77 & 3 & 75 \\
\hline 5 & 75 & 2 & 75 \\
\hline 6 & 70 & 3 & 75 \\
\hline 7 & 65 & 3 & 75 \\
\hline 8 & 60 & 4 & 75 \\
\hline 9 & 55 & 6 & 75 \\
\hline 10 & 50 & 4 & 75 \\
\hline Total & & 30 & \\
\hline
\end{tabular}

Based on table 3.1. A total of 10 students scored $\geq 75$ obtained from the pre-test and 20 students scored $<75$. The data can be seen from the number of frequencies of students who scored 74 and below. Based on the data above, it can be seen that student learning outcomes are still low, it can be seen from the scores of students who still get a lot of scores below the KKM. The results of student achievement are still low. This is due to 1) Students ignore ongoing learning. 2) Many students chat with their friends, and other students play with their writing tools to explain the lesson. 3) Students are still lacking enthusiasm for participating in learning. 4) Students do not dare to express their opinion. 5. Students are less active in learning. Therefore, it is necessary to improve the learning outcomes of IPs for grade V SD Borong Jambu II Makassar.

\section{Cycle I}

The data obtained from the pre-action stage is used to implement the first cycle of action. The action stages in the first cycle are as follows. Researchers compile a plan implemented in the first cycle of action to improve social studies learning outcomes for fifth-grade students of SD Borong Jambu II Makassar. Then the teacher distributes student worksheets or worksheets to each group. Students began to discuss in answering the LKS questions so that some students had not seen their 
contribution in working on the LKS. The teacher calls the group representatives to present the discussion results in front of the class, starting from group 1 to group 6. After each group has delivered its presentation, the teacher offers the other groups to give questions or rebuttals to the group that has provided the presentation. Students who dare to submit their responses are rewarded by the teacher in the form of praise and applause.

The next meeting was held as a follow-up action and improved the learning process at the first meeting. The social studies material taught on the preparation for independence with indicators shows an attitude of respect for the leaders' services. It can identify the role of several figures in fighting for independence. As an initial activity, the teacher tells the biography of one of the leaders in preparation for Indonesian independence and asks about the material studied at the previous meeting, and asks about students' difficulties at home. The teacher explains the scheme for the preparation for independence to students. Each group made a presentation by bringing a scheme of preparatory events for independence and explaining it. The teacher asks students to do questions and answers for students who still do not understand the material presented by other groups. The teacher first accommodates all students' responses, does not blame, and do not justify. This question is used to see how much knowledge students have about the events of Indonesian independence. The teacher gives rewards in the form of praise and asks students to applaud their friends who dare to express answers to the teacher's questions. After students' express answers to their friends' questions, the teacher begins to discuss and briefly explain the events of the proclamation of Indonesian independence. As a follow-up, the teacher provides input to students in making a good material scheme and how a good percentage is.

Then the teacher makes groups. The group is different from the previous group. This group has begun to be divided based on students' abilities and character to form a heterogeneous group. The teacher distributes worksheets to each group, and then the students are asked to work on it by discussing it with their respective groups. After the appointed time to work on the worksheets is over, each group representative is requested to present his group discussion results. After the group has finished delivering the discussion results, the teacher provides other groups' opportunities to respond. For all groups to be active in the question and answer process, the teacher requires each group to give questions or suggestions. Then the researcher corrects the answers to the student evaluation questions. From these answers, data is obtained in the form of numbers, which are each student's scores. The scores obtained by students in cycle I are in Table 2.

Table 2. Distribution of Frequency Value of Achievement of Social Sciences Learning Outcomes in Cycle I

\begin{tabular}{cccc}
\hline No. & Score & Frequency & KKM \\
\hline 1 & 95 & 2 & 75 \\
\hline 2 & 85 & 4 & 75 \\
\hline 3 & 80 & 3 & 75 \\
\hline 4 & 77 & 5 & 75 \\
\hline 5 & 75 & 4 & 75 \\
\hline 6 & 70 & 3 & 75 \\
\hline 7 & 65 & 3 & 75 \\
\hline 8 & 60 & 4 & 75 \\
\hline 9 & 55 & 2 & 75 \\
\hline 10 & 50 & - & 75 \\
\hline
\end{tabular}

Based on the data above, it can be concluded that the fifth-grade students of SD Borong Jambu II Makassar, as many as 18 students or $60 \%$ who get a value $\geq$ of 75 , the data can be seen from the number of frequencies of students who score 75 and above. Meanwhile, as many as 12 students or $40 \%$ obtained a value $<75$. The data can be seen from the frequencies of students who scored 74 and below. The following in Table 8 is presented a comparison of social studies learning outcomes Preaction and Cycle I. 
Table 3. Comparison of Pre-Action and Cycle I Social Studies Learning Outcomes

\begin{tabular}{ccccc}
\hline \multirow{2}{*}{$\begin{array}{l}\text { Success } \\
\text { Criteria }\end{array}$} & \multicolumn{2}{c}{ Pra Action } & \multicolumn{2}{c}{ Cycle I } \\
\cline { 2 - 5 } & Number Of Students & Percentage (\%) & Number of Students & Percentage (\%) \\
\hline Score $\geq 75$ & 10 & $33,33 \%$ & 18 & $60 \%$ \\
\hline Score $<75$ & 20 & $66,66 \%$ & 12 & $40 \%$ \\
\hline
\end{tabular}

In the pre-action results, only ten students scored $\geq 75$ or $33.33 \%$. After participating in learning using the quantum teaching model, the number of students who scored $\geq 75$ became 18 students or $60 \%$, so that the average class score increased. Student social studies learning outcomes in cycle I have started to increase compared to pre-action, namely from 20 students or $66.66 \%$ to 12 students or $40 \%$ who get a value $<75$ or below 74 , but have not met the indicators of success in this research because All students have not reached a score of $\geq 75$. Because the criteria for success in this study have not been fulfilled, all students have not got $\geq 75$, and the research will continue to cycle II.

Based on observations in the use of the Quantum Teaching model in the form of observation sheets carried out by teachers and students in social studies learning in cycle I for two meetings. Observations were made to see the affective and psychomotor domains of students and teachers in learning. The teacher's learning activities follow the plan for implementing quantum teaching, known as Tandur, which has been previously designed. During learning, the teacher has provided information about the objectives and benefits of learning and guides students to use various sources and provide rewards. The observation of the first meeting showed that almost all students were active in learning activities. However, there were still students who joked and were not serious about taking part in learning, this can be seen from the results of group collaboration that were not optimal. As well as the lack of student interest in making conclusions from learning activities. Learning activities using the quantum teaching model are visible but not yet optimal.

The naming steps at meetings 1 and 2 are carried out by working on group assignments. Some students are lacking in working with friends and colleagues so that the task is not optimal. By dividing the groups in alphabetical order, there is a gap between students, namely students who do not match the group's theme. This causes cooperation in carrying out group assignments not to run smoothly or not well. Group presentations carried out the demonstration step in meetings 1 and 2. The order of group presentations is following the order of the groups. This causes the final group not to pay attention to the group representatives presenting. Repeat and celebrate steps are good enough at meetings 1 and 2. The teacher reviews and rewrites the material learned by asking and answering questions with students, then students are then asked to record it in their respective notebooks. The teacher gives praise to students and claps with the students at the end of the meeting.

\section{Reflection}

Based on the observations made using the quantum teaching model in the learning process, it has been running effectively. The quantum teaching model made some students more enthusiastic about participating in the learning process, especially when the teacher showed a video about the material to prepare for Indonesian independence. The quantum teaching model makes it easy for teachers to interact directly with students through songs and questions and answers about the material being taught. The use of the quantum teaching model provides rewards to students through appreciation with praise and applause so that students feel happy. Using the quantum teaching model can be seen from the student learning outcomes in the first cycle that has increased compared to pre-action. This can be overcome by rearranging the division of groups based on students' abilities and characters to create heterogeneous groups that complement each other.

\section{Cycle II}

Implementing the action in cycle II aims to ensure that all students' social studies learning outcomes score $\geq$ The material on preparation for independence to be taught in cycle II uses the quantum teaching model. The first stage carried out in cycle II is to arrange learning improvements in cycle II to overcome various deficiencies in cycle I. In cycle II it is carried out in two meetings. After learning is complete, the teacher and students reflect by providing opportunities for students to argue about today's learning activities, such as being empowered about material that is not clear, and what 
difficulties students encounter while taking lessons. As well as concluding the learning activities that have been implemented. The teacher then evaluates the questions that are done individually to see the level of achievement of student learning outcomes. After finishing working on the questions, students were asked by the teacher to exchange the answer sheets with their friends. The results of student work are collected to be assessed and corrected then the teacher guides students to discuss answers to these questions. The results of the scores obtained by students in cycle II can be presented in the table.

Table 4. Distribution of Frequency Value of Achievement of Social Studies Learning Outcomes in Cycle II

\begin{tabular}{ccc}
\hline No. & Score & Frequency \\
\hline 1 & 100 & 2 \\
\hline 2 & 90 & 4 \\
\hline 3 & 85 & 6 \\
\hline 4 & 80 & 11 \\
\hline 5 & 75 & Total \\
\hline
\end{tabular}

The table above showed that in cycle II, all students scored $\geq 75$ with an average score of 83.2. Thus, the social studies learning outcomes in cycle II have increased and follow the success indicators in this study. The following in Table 5 is presented a comparison of the learning outcomes of the IPs Pre-action, cycle I, and cycle II.

Table 5. Comparison of Pre-Action Social Studies Learning Outcomes, Cycle I, and Cycle II

\begin{tabular}{ccccccc}
\hline & \multicolumn{2}{c}{ Pra Action } & \multicolumn{2}{c}{ Cycle I } & \multicolumn{2}{c}{ Cycle II } \\
\cline { 2 - 7 } Success Criteria & Number of Students & $(\%)$ & $\begin{array}{c}\text { Number of } \\
\text { Students }\end{array}$ & $(\%)$ & $\begin{array}{c}\text { Number of } \\
\text { Students }\end{array}$ & $(\%)$ \\
\hline Score $\geq 75$ & 10 & $33,33 \%$ & 18 & $60 \%$ & 30 & $100 \%$ \\
\hline Score $<75$ & 20 & $66,66 \%$ & 12 & $40 \%$ & 0 & $0 \%$ \\
\hline Mean Score & & & & & \\
\hline
\end{tabular}

Table 5 showed that pre-action results are only ten students or $33.33 \%$ who get a value of $\geq 75$. After learning using the quantum teaching model, it increases to 18 students or by $60 \%$ in cycle I, it rises again to 30 students or all students get value $\geq 75$ in cycle II. Learning using the quantum teaching model by doing variations shows that the criteria for success in the research are fulfilled. It can be seen from the increase in students' social studies scores.

The observations show that the use of the quantum teaching model in the learning process is progressing better. Teachers are more varied in providing stories related to students' daily lives. Students are already active and are starting to be interested in learning materials about preparation for independence. This is evidenced by the increasing percentage of students' affective and psychomotor domains.

Apperception is used to explore students' initial understanding of mastering the subject matter. Furthermore, the teacher provides a brief explanation of the material then divides the students into several groups. The teacher distributes worksheets to be discussed with their group friends. The teacher goes around and guides each group. 
Several groups looked serious in conducting a question, answering questions, and having discussions with their group of friends because they were interested in the teacher's questions. Several groups began to appear to divide their group assignments, such as reading questions, writing, and discussing answers to questions.

It shows that students who were initially shy dared to express their opinions, and slow students experienced an increase in learning outcomes. At the second meeting, the end of the second cycle was closed with an evaluation to measure student learning outcomes and see the extent of students' understanding of the material that had been taught. The teacher sees student work during the assessment, the class atmosphere looks calmer, and all students are serious about working on the questions. The teacher asks students who have finished working on the questions to be asked to examine their answers again.

After the time ended in working on the questions, the teacher asked the students to exchange their classmates' answers. The teacher asks several students to read the answers. At the end of the meeting, the teacher guides students to make conclusions, advises students to continue learning, be diligent in asking questions if they do not understand, and like to read so that they are smarter and can move up to class with good grades.

\section{Reflection}

The data obtained from the implementation of the action in cycle II found no serious obstacles, the lesson plan (RPP) had been carried out well, and the learning aspects using the quantum teaching model had also been fulfilled. This can be seen from the active students in group discussions and cooperation in working on group assignments. The TANDUR step in cycle II has seen an increase compared to cycle I. The teacher needs to vary the degrees again in giving questions so that the TANDUR steps run even better.

The use of the quantum teaching model in social studies learning can improve learning achievement in grade V students at SD Borong Jambu II Makassar, especially in preparation for Indonesian independence. This can be seen based on the second cycle test results, namely 30 students $(100 \%)$ who have met the value $\geq$ 75 or all students have reached the success criteria. Thus, the study was stopped and not continued in the next cycle.

\section{Conclusion}

Based on the results of research and discussion, it can be concluded that the quantum teaching model improves social studies learning outcomes for fifth-grade students of SD Borong Jambu II Makassar by varying the TANDUR steps; steps to grow by giving songs, natural steps by providing direct experience, steps named by giving assignments, demonstration steps by presenting, steps repeat with questions and answers, and efforts to celebrate with giving praise. Division of discussion groups based on students' abilities and characteristics. This increase can be seen in the rise of achievement value percentage before the action is carried out until each cycle the results of the pre-action test evidenced this, cycle I and cycle II

\section{References}

Allen, IE, Seamen, J. \& Garret, R. (2007). Blending in: The extent and promise of blended education in the United States, USA: The Sloan Consortium.

A'la, M. (2010). Quantum Teaching. Smart and Practical Book. Jogjakarta. DIVA Press.

Aqib, Zaenal. (2009). Classroom action research. Bandung: Yrama Widya

DePorter, B. Reardon, M. Nourie-Singer, S. (2012). Quantum Teaching. Practicing Quantum Learning in Classrooms. Bandung: PT Mizan Pustaka.

Miftahul A'la. (2010). Quantum Teaching (Smart and Practical Book). Yogyakarta: Diva Press.

Rofidah Nuraningsih, (2009). Efforts to Improve Reading and Writing Skills with Image Media in Class II Indonesian Language Subjects B Ngawen Gunung Kidul (Penekatan Penelitian Tindakan Kelas)" http:/ / file.upi.edu/Direktori/DUALMODES/

Pendidikan_Bahasa_Dan_Sastra_Indonesia_Di_Sekolah_Dasar_Kelas Rendah/Bbm_3.pdf, diakses 30 Juni 2019 pukul 09.32

Sugiyono. (2012). Qualitative, Quantitative, and Combined Research Methods (Mixed Methods). Bandung: CV. Alfabeta.

Sujarwo; Sukmawati; Yahrif, M. (2019). Celebes Education Review: Improving Students' English Learning Outcomes through PQ4R (Preview, Question, Read, Reflect, Recite, Review) Learning Model at the Eighth Grade Students of SMP Tunas Bangsa Makassar. 1, 48-55. https://doi.org/https://doi.org/10.37541/cer.v1i2.228

Sujarwo, S., Akhiruddin, A., Salemuddin, M. R., Sabillah, B. M., \& Sriwahyuni, S. (2019). The Application of Problem Solving Reasoning (PSR) in Improving Students' Metacognitive at the Twelfth Grade Students 
of SMAN 19 Makassar. International Journal for Educational and Vocational Studies, 1(2), 138-141. https://doi.org/10.29103/ijevs.v1i2.1525

Suprijono, Agus. (2010). Cooperative Learning Theory and Application PAIKEM. Yogyakarta: Pustaka Pelajar.

Susiani, K dkk. (2013). The Effect of the Quantum Learning Model on the Socio-Emotional Intelligence and Science Learning Achievement of Class Students V SD Bayuning. Jurnal Penelitian Pendidikan Dasar (online). Vol. 03 tahun 2013. Diakses pada tanggal 3 Juli 2019.

Trianto. (2010). Designing Progressive Innovative Learning Models. Jakarta: Kencana. 